\title{
Producing Eggplant under Incorporation of Rice Straw into Clayey Soil with Decomposing Fungi and Plant Growth Promoting Rhizobacteria
}

\author{
S. A. Abd El-Aziz", M. A. Abdrabbo**, F. A. Hashem**, A. A. \\ Farag $^{* *}$ and H. H. Abotaleb ${ }^{* * *}$ \\ ${ }^{*}$ Central Lab of Organic Agricultural ${ }^{* * *}$ Central Laboratory for \\ Agricultural Climate ${ }^{* * * *}$ Agricultural MicrobialDepartment, Soils, \\ Water and Environment Research Institute, Agricultural \\ Research Centre, Cairo, Egypt.
}

IELD experiments were conducted at the experimental Site of
Central Laboratory for Agricultural Climate (CLAC),
Agricultural Research Center, Giza, Egypt during 2013 and 2014
seasons. The objective of this study was to investigate the effect of
applying rice straw into soil with or without rice straw decomposing
fungi (RSDF) and plant growth promoting rhizobacteria (PGPR)
under 50 and $100 \%$ of recommended NPK on eggplant production. A
randomized complete block design was used with three replications.
Liquid culture of Trichoderma viride was used as RSDF. Mixture of
Azotobacter chroococcum, Azospirillium brasilense, Bacillus
megaterium and Bacillus circulans were used as PGPR. The control
treatment under this study was application of 100\% NPK without
application of rice straw. The obtained results showed that growth
characteristics, mineral composition and yield component of eggplant
cultivar Black Balady were significantly improved by applying 100\%
mineral fertilizers with rice straw plus PGPR with or without RSDF.
Using 50\% mineral fertilizers with rice straw plus RSDF and PGPR
gave good yield with no significant differences in comparing with
$100 \%$ mineral fertilizers without rice straw (control). This work shows
that incorporation of rice straw into soil with decomposing fungi and
plant growth promoting rhizobacteria led to improve the production of
eggplant. As well as, reduce the amount of mineral fertilizers and
avoid one of the most serious environmental air pollution (Black
Cloud), caused by burning rice straw annually.

Keywords: Eggplant, Rice straw, Rice straw decomposing fungi, Trichoderma viride, Plant growth promoting rizobacteria (PGPR).

Eggplant (Solanum melongena var. esculenta $L$ ) is one of the important vegetable crops grown in the summer season of Egypt. The total cultivated area in Egypt was about 108 thousand feddans, producing about 1.2 million tons on annual basis with an average of 11.1 tons/feddan (feddan equal 0.4 hectare) according to Ministry of Agriculture and Land Reclamation (2013). Eggplant fruits contain a considerable amount of carbohydrates $(6.4 \%)$, protein $(1.3 \%)$ and 
fat $(0.3 \%)$. They are also a rich source of potassium, magnesium, calcium and iron (Zenia and Halina, 2008).

The problem of agricultural wastes in Egypt became very obvious especially after the harvest of summer crops. Egyptian farmers get rid of these wastes by burning. Burning not only is considered an economic loss but also has harmful effects on the environment, i.e. emission of poison gases to the air and reducing the microbial activities in the soil. Therefore, utilization of agriculture wastes in any other environmentally friendly way is very important (Abou Hussein and Sawan, 2010).

The decomposition of crop stalks biomass in the soil improved the soil fertility by supplying organic matter, plant nutrients and improving the soil texture (Yu \& Song, 2003, Abdulla, 2007 and Dai et al., 2010). As well as, soil microbial structure and population. (Glinwood et al., 2011 and Hou et al., 2012).

Decomposition of rice straw is due to the activity of many types of microorganisms, i.e. bacteria and fungi (Sirisena \& Manamendra 1995 and Kausar et al. 2010). Fungi, i.e. Aspergillus, Fusarium, Trichoderma, Chyptoga, Mucor sp. the main decomposer agents that can break down the rice straw (Nandi et al. 2000). Fungal inoculates can accelerate the decomposition of rice straw. Trichoderma sp. is the best indigenous fungi in the decomposition process of rice straw (Irfan et al. 2010).

Plant growth promoting rhizobacteria are naturally occurring soil bacteria that aggressively colonize plant roots and benefit plants by providing growth promotion. Inoculation of crop plants with certain strains of PGPR at an early stage of development can improve biomass production through direct effects on root and shoot growth. Inoculation of vegetables with PGPR may result in multiple effects as seen in the enhancement of seed germination, stand health, plant vigor, nutrients content of plant tissues, early bloom and chlorophyll content (Joseph et al., 2007). PGPR influenced the growth, yield, and increase supply with different nutrients, such as nitrogen, phosphorus, potas sium, sulphur, iron and copper, produce plant hormones, enhance other beneficial bacteria or fungi (Saharan and Nehra 2011).

This work aimed to study possibility application of rice straw into soil with or without rice straw decomposing fungi and plant growth promoting rhizobacteria, as a good agriculture practices to improve the production of eggplant, and avoid the serious environmental air pollution (Black Cloud), caused by burning rice straw annually.

\section{Materials and Methods}

The field experiments were carried out during the two growing summer seasons of 2013 and 2014 at Central Laboratory for Agricultural Climate (CLAC), Agriculture Research Center, Egypt. Eggplant seedlings (cultivar Black

Egypt. J. Hort. Vol. 42, No. 2 (2015) 
Balady) were planted in the field on 24 and 20 of February in the first and second seasons, respectively. The experimental trial was conducted in clay soil using drip irrigation system. Emitter discharge rate was $4 \mathrm{l} / \mathrm{hr}$, the distance between emitters was $0.5 \mathrm{~m}$. Physical and chemical properties of the experimental soil were analyzed before cultivation according to FAO (1980) in Table 1.

TABLE 1. Physical and chemical analyses of the experimental soil.

\begin{tabular}{|c|c|c|c|c|c|c|c|c|c|c|c|c|c|}
\hline \multirow{2}{*}{$\underset{\%}{\text { Clay }}$} & \multirow{2}{*}{$\begin{array}{c}\text { Silt } \\
\%\end{array}$} & \multirow{2}{*}{$\underset{\%}{\text { Sand }}$} & \multirow{2}{*}{ Texture } & \multirow{2}{*}{ pH } & \multirow{2}{*}{$\begin{array}{c}\mathrm{EC} \\
\mathrm{dS} / \mathrm{m}\end{array}$} & \multicolumn{4}{|c|}{ Cations meq/l } & \multicolumn{4}{|c|}{ Anions meq/l } \\
\hline & & & & & & $\mathrm{Ca}^{++}$ & $\mathbf{M g}^{++}$ & $\mathbf{K}^{+}$ & $\mathbf{N a}^{+}$ & $\mathrm{Co}_{3}$ & $\mathrm{HCO}_{3}$ & $\mathrm{Cl}^{-}$ & $\mathrm{SO}_{4}{ }^{=}$ \\
\hline 67.60 & 18.56 & 13.84 & Clay & 7.76 & 1.33 & 2.58 & 0.94 & 1.82 & 1.94 & - & 1.92 & 2.38 & 3.25 \\
\hline
\end{tabular}

The soil of the experiment was ploughed and divided into ridges, each plot contained three ridges $0.80 \mathrm{~m}$ width and $5 \mathrm{~m}$ length. The space between plants was $0.50 \mathrm{~m}$ on one side of ridge. Two ton/feddan $\left(0.5 \mathrm{~kg} / \mathrm{m}^{2}\right)$ of rice straw were incorporated into experiment soil during soil preparation except control treatment. The main chemical analyses of rice straw are shown in Table 2. Incorporation rice straw into soil was applied before transplanting date by two weeks.

TABLE 2. Chemical composition of the rice straw.

\begin{tabular}{|c|c|c|c|c|c|c|c|}
\hline $\begin{array}{c}\text { DM } \\
(\boldsymbol{\%})\end{array}$ & $\begin{array}{c}\text { Ash } \\
(\boldsymbol{\%})\end{array}$ & $\begin{array}{c}\text { O.C } \\
(\boldsymbol{\%})\end{array}$ & $\begin{array}{c}\text { C/N } \\
\text { ratio }\end{array}$ & $\begin{array}{c}\mathbf{p H} \\
\mathbf{1 : 5}\end{array}$ & $\mathbf{N}$ & \multicolumn{3}{|c|}{$\mathbf{P}$} & $\mathbf{K})$ \\
\hline 92.42 & 17.56 & 31.16 & 67.73 & 6.46 & 0.48 & 0.056 & 1.53 \\
\hline
\end{tabular}

The recommended dose of NPK as mineral fertilizers (MF) were applied according to Ministry of Agriculture and Land Reclamation (2009) as follows: $140 \mathrm{~kg} \mathrm{~N} / \mathrm{fed}(\mathrm{fed}=0.4 \mathrm{ha})$ as $683 \mathrm{~kg}$ ammonium sulphate $(20.5 \% \mathrm{~N}), 45 \mathrm{~kg}$ $\mathrm{P}_{2} \mathrm{O}_{5} /$ fed as $290 \mathrm{~kg}$ calcium super phosphate $\left(15.5 \% \mathrm{P}_{2} \mathrm{O}_{5}\right)$ and $48 \mathrm{~kg} \mathrm{~K}_{2} \mathrm{O} / \mathrm{fed}$ as $100 \mathrm{~kg}$ potassium sulphate $\left(48 \% \mathrm{~K}_{2} \mathrm{O}\right)$. Calcium super phosphate was added as one dose during soil preparation, whereas ammonium sulphate and potassium sulphate were added at three equal portions, during soil preparation, after 21 and 45 days from transplanting. Half of the abovementioned quantities $(70 \mathrm{~kg} \mathrm{~N} /$ Fed., $22.5 \mathrm{P}_{2} \mathrm{O}_{5} /$ fed and $24 \mathrm{~K}_{2} \mathrm{O} / \mathrm{fed}$ ) of mineral fertilizers were applied at the same times with $50 \%$ MF treatments.

All microorganisms (pure local strains) were kindly provided by the Microbiology Dept. Soil, Water and Environment Research Institute, Agricultural Research Center. Trichoderma viride as rice straw decomposing fungi (RSDF) was supplemented to the soil by using liquid culture at a rate of 10 Lfeddan (1ml contains $10^{7}$ cell) directly after rice straw incorporation and irrigation. 
Plant growth promoting rhizobacteria (PGPR) were used as mixture of Azotobacter chroococcum, Azospirillium brasilense (nitrogen fixing bacteria), Bacillus megaterium (phosphate dissolving bacteria) and Bacillus circulans (potassium releasing bacteria). PGPR were supplemented to the soil surface beside plants after 2 and 4 weeks from transplanting by using liquid cultures at a rate of $20 \mathrm{ml} /$ plant ( $1 \mathrm{ml}$ contains $10^{8}$ cell) according to Mashhoor et al. (2002) after diluted by water without Chlorine at $1: 20$ rate.

\section{The Experimental Treatments}

- Recommended dose of NPK as mineral fertilizers without rice straw $(100 \%$ $\mathrm{MF})$.

- $100 \% \mathrm{MF}+$ rice straw $(100 \% \mathrm{MF}+\mathrm{RS})$.

- $100 \% \mathrm{MF}+$ rice straw + rice straw decomposing fungi $(100 \% \mathrm{MF}+\mathrm{RS}+$ RSDF).

- $100 \% \mathrm{MF}+$ rice straw + plant growth promoting rhizobacteria $(100 \% \mathrm{MF}+$ $\mathrm{RS}+\mathrm{PGPR})$.

- $100 \% \mathrm{MF}+$ rice straw + rice straw decomposing fungi + plant growth promoting rhizobacteria (100\% $\mathrm{MF}+\mathrm{RS}+\mathrm{RSDF}+\mathrm{PGPR})$.

- $50 \% \mathrm{MF}+\mathrm{RS}$

- $50 \% \mathrm{MF}+\mathrm{RS}+\mathrm{RSDF}$

- $50 \% \mathrm{MF}+\mathrm{RS}+\mathrm{PGPR}$

- $50 \% \mathrm{MF}+\mathrm{RS}+\mathrm{RSDF}+\mathrm{PGPR}$

The experiment was arranged in a completely randomized block design, with three replicates for each treatment.

After 60 days from transplanting, three plants per replicate were randomly chosen to measure plant height, stem diameter (under the first bottom leaf directly), number of leaves/plant, chlorophyll reading in the fourth upper leaf by using Minolta Chlorophyll Meter Spad 501. Total nitrogen, phosphorous and potassium percentage were determined in the dry matter of fourth upper leaf according to Cottenie et al. (1982). Total nitrogen was determined by Kjeldahl method according to the procedure described by FAO (1980). Phosphorus percentage was determined using spectrophotometer according to Watanabe and Olsen (1965). Potassium percentage was determined spectrometrically using Phillips Unicum Atomic Absorption Spectrometer as described by Chapman and Pratt (1961). Fresh and dry shoot weight was measured at harvesting. Early yield (recorded during the first two harvests) and total yield for each plot were recorded after each harvesting accumulatively and were collected per meter square.

Data of the two seasons were analyzed statistically by the analysis of variance using one way ANOVA according to Snedecor and Cochran (1980) with using SAS package. Comparison of treatment means was done using Tukey test at significance level 0.05 . 


\section{Results and Discussion}

Vegetative characteristics of eggplant plants as affected by the different treatments are presented in Tables 3 and 4 . The results showed that the treatments of $100 \%$ MF plus rice straw plus plant growth promoting rhizobacteria (PGPR) with or without rice straw decomposing fungi (RSDF) significantly increased vegetative growth of eggplant plants, these treatments gave the highest values of vegetative characteristics expressed as fresh and dry shoot weight, leaves number, plant height, stem diameter and chlorophyll reading compared to the other tested treatments. The treatments of $100 \% \mathrm{MF}$ plus rice straw with or without RSDF increased of fresh and dry shoot weight compared to $100 \% \mathrm{MF}$ without rice straw treatment, while there were no significant differences among these treatments in other vegetative characteristics. On the other hand, the treatments of 50\% MF plus rice straw plus PGPR with or without RSDF decreased of fresh, dry shoot weight and plant height compared to $100 \% \mathrm{MF}$ without rice straw treatment, while there were no significant differences among these treatments in other vegetative characteristics. Whereas, 50\% MF plus rice straw with or without RSDF gave the lowest vegetative characteristics during the two growing seasons. The positive effect of $100 \%$ MF plus rice straw plus PGPR with or without RSDF treatments might be due to the decomposition of rice straw in the soil, that improved the soil fertility by supplying organic matter and improving the soil texture (Yu \& Song, 2003 and Abdulla, 2007). This effect might also be due to the beneficial effects of PGPR, that help in increasing nitrogen fixation in rhizosphere, increase supply of other nutrients and produce plant hormones (Saharan and Nehra, 2011). All these led to improve the plant growth. These results are in agreement with those obtained by Joseph et al. (2007) on chickpea, Glinwood et al. (2011), Hou et al. (2012) on hot pepper and Latha et al. (2014) on eggplant.

TABLE 3. Effect of incorporation of rice straw into soil with RSDF and PGPR on fresh, dry weight and leaf number of eggplant plants during 2013 and 2014 seasons.

\begin{tabular}{|c|c|c|c|c|c|c|}
\hline \multirow{2}{*}{ Treatments } & \multicolumn{2}{|c|}{$\begin{array}{c}\text { Fresh weight } \\
\text { g/plant }\end{array}$} & \multicolumn{2}{|c|}{$\begin{array}{c}\text { Dry weight } \\
\text { g/plant }\end{array}$} & \multicolumn{2}{|c|}{ Leaf No/plant } \\
\hline & $\begin{array}{c}1^{s t} \\
\text { season } \\
\end{array}$ & $\begin{array}{c}2^{\text {nd }} \\
\text { season }\end{array}$ & $\begin{array}{c}1^{\text {st }} \\
\text { season } \\
\end{array}$ & $\begin{array}{c}2^{n d} \\
\text { season }\end{array}$ & $\begin{array}{c}1^{s t} \\
\text { season } \\
\end{array}$ & $\begin{array}{c}2^{\text {nd }} \\
\text { season }\end{array}$ \\
\hline $100 \% \mathrm{MF}$ (control) & $950 \mathrm{~d}$ & $958 \mathrm{~d}$ & $266 \mathrm{c}$ & $270 \mathrm{c}$ & $32.33 \mathrm{c}$ & $33.33 \mathrm{bc}$ \\
\hline $100 \% \mathrm{MF}+\mathrm{RS}$ & $1033 \mathrm{c}$ & $1050 \mathrm{c}$ & $284 b$ & $287 b$ & $32.67 \mathrm{c}$ & $33.43 \mathrm{bc}$ \\
\hline $100 \% \mathrm{MF}+\mathrm{RS}+\mathrm{RSDF}$ & $1087 \mathrm{c}$ & $1092 \mathrm{c}$ & $289 b$ & $291 b$ & $33.00 \mathrm{c}$ & $34.33 \mathrm{~b}$ \\
\hline $100 \% \mathrm{MF}+\mathrm{RS}+\mathrm{PGPR}$ & $1225 b$ & $1247 \mathrm{~b}$ & $320 \mathrm{a}$ & $326 \mathrm{a}$ & $37.67 \mathrm{~b}$ & $39.33 \mathrm{a}$ \\
\hline $100 \% \mathrm{MF}+\mathrm{RS}+\mathrm{RSDF}+\mathrm{PGPR}$ & $1300 \mathrm{a}$ & $1310 \mathrm{a}$ & $333 \mathrm{a}$ & $336 \mathrm{a}$ & $40.67 \mathrm{a}$ & $41.67 \mathrm{a}$ \\
\hline $50 \% \mathrm{MF}+\mathrm{RS}$ & $710 \mathrm{f}$ & $717 \mathrm{f}$ & $193 \mathrm{f}$ & $194 f$ & $25.67 \mathrm{~d}$ & $26.33 d$ \\
\hline $50 \% \mathrm{MF}+\mathrm{RS}+\mathrm{RSDF}$ & $740 \mathrm{f}$ & $750 f$ & $189 \mathrm{f}$ & $192 \mathrm{f}$ & $26.33 \mathrm{~d}$ & $27.33 \mathrm{~d}$ \\
\hline $50 \% \mathrm{MF}+\mathrm{RS}+\mathrm{PGPR}$ & $830 \mathrm{e}$ & $853 \mathrm{e}$ & $214 \mathrm{e}$ & $220 \mathrm{e}$ & $30.33 \mathrm{c}$ & $30.67 \mathrm{c}$ \\
\hline $50 \% \mathrm{MF}+\mathrm{RS}+\mathrm{RSDF}+\mathrm{PGPR}$ & $883 \mathrm{e}$ & $897 \mathrm{e}$ & $236 \mathrm{~d}$ & $240 d$ & $30.67 \mathrm{c}$ & $31.33 \mathrm{bc}$ \\
\hline
\end{tabular}

Means in same column by similar letters are not statistically different at 0.05 level according to Tukey test. $\mathrm{MF}=$ mineral fertilizer $\mathrm{RS} \quad=$ rice straw

$\mathrm{RSDF}=$ rice straw decomposing fungi

$\mathrm{PGPR}=$ plant growth promoting rhizobacteria

Egypt. J. Hort. Vol. 42, No. 2 (2015) 
TABLE 4. Effect of incorporation of rice straw into soil with RSDF and PGPR on plant height, stem diameter and chlorophyll reading of eggplant plants during 2013 and 2014 seasons.

\begin{tabular}{|c|c|c|c|c|c|c|}
\hline \multirow{2}{*}{ Treatments } & \multicolumn{2}{|c|}{$\begin{array}{c}\text { Plant height } \\
\text { cm }\end{array}$} & \multicolumn{2}{|c|}{$\begin{array}{c}\text { Stem diameter } \\
\mathbf{m m}\end{array}$} & \multicolumn{2}{|c|}{$\begin{array}{c}\text { Chlorophyll } \\
\text { reading } \\
\text { spad }\end{array}$} \\
\hline & $\begin{array}{c}1^{\text {st }} \\
\text { season }\end{array}$ & $\begin{array}{c}2^{\text {nd }} \\
\text { season }\end{array}$ & $\begin{array}{c}1^{\text {st }} \\
\text { season }\end{array}$ & $\begin{array}{c}2^{\text {nd }} \\
\text { season }\end{array}$ & $\begin{array}{c}1^{s t} \\
\text { season }\end{array}$ & $\begin{array}{c}2^{\text {nd }} \\
\text { season }\end{array}$ \\
\hline $100 \% \mathrm{MF}$ (control) & $77.00 \mathrm{~b}$ & $79.33 \mathrm{~cd}$ & $13.00 \mathrm{~b}$ & $13.78 \mathrm{~cd}$ & $41.30 \mathrm{bc}$ & $42.29 \mathrm{bc}$ \\
\hline $100 \% \mathrm{MF}+\mathrm{RS}$ & $76.67 b$ & $79.67 \mathrm{~cd}$ & $13.33 b$ & $14.12 \mathrm{c}$ & $42.00 \mathrm{~b}$ & $42.99 \mathrm{~b}$ \\
\hline $100 \% \mathrm{MF}+\mathrm{RS}+\mathrm{RSDF}$ & $78.67 \mathrm{~b}$ & $82.33 b c$ & $13.33 b$ & $14.39 \mathrm{bc}$ & $42.23 b$ & $43.22 \mathrm{~b}$ \\
\hline $100 \% \mathrm{MF}+\mathrm{RS}+\mathrm{PGPR}$ & $84.67 \mathrm{a}$ & $88.33 \mathrm{ab}$ & $16.00 \mathrm{a}$ & $16.54 \mathrm{ab}$ & $44.13 \mathrm{a}$ & $45.12 \mathrm{a}$ \\
\hline $100 \% \mathrm{MF}+\mathrm{RS}+\mathrm{RSDF}+\mathrm{PGPR}$ & $90.00 \mathrm{a}$ & $92.67 \mathrm{a}$ & $16.33 a$ & $16.89 \mathrm{a}$ & $44.60 \mathrm{a}$ & $45.59 \mathrm{a}$ \\
\hline $50 \% \mathrm{MF}+\mathrm{RS}$ & $56.67 \mathrm{~d}$ & $57.33 \mathrm{f}$ & $8.33 \mathrm{c}$ & $8.62 \mathrm{f}$ & $37.07 \mathrm{~d}$ & $38.05 \mathrm{~d}$ \\
\hline $50 \% \mathrm{MF}+\mathrm{RS}+\mathrm{RSDF}$ & $59.33 \mathrm{~d}$ & $61.33 \mathrm{f}$ & $8.67 \mathrm{c}$ & 9.98 ef & $38.03 \mathrm{~d}$ & $38.82 \mathrm{~d}$ \\
\hline $50 \% \mathrm{MF}+\mathrm{RS}+\mathrm{PGPR}$ & $68.67 \mathrm{c}$ & $72.00 \mathrm{e}$ & $11.50 \mathrm{~b}$ & $11.89 \mathrm{de}$ & $40.13 \mathrm{c}$ & $40.62 \mathrm{c}$ \\
\hline $50 \% \mathrm{MF}+\mathrm{RS}+\mathrm{RSDF}+\mathrm{PGPR}$ & $70.67 c$ & $74.00 \mathrm{de}$ & $11.67 \mathrm{~b}$ & $12.32 \mathrm{~cd}$ & $40.8 \mathrm{bc}$ & $41.287 \mathrm{c}$ \\
\hline
\end{tabular}

Means in same column by similar letters are not statistically different at 0.05 level according to Tukey test.

$\mathrm{RS} \quad=$ rice straw

$\mathrm{RSDF}=$ rice straw decomposing fungi

PGPR = plant growth promoting rhizobacteria

The effect of treatments on the nutritional status in eggplant plants is shown in Table 5. The obtained results in both seasons revealed that application of $100 \%$ MF plus rice straw plus PGPR with or without RSDF treatments gave the highest concentrations of N, P and $\mathrm{K}$ in eggplant leaves. On the other hand, the lowest N, P and K percentage of eggplant leaves were obtained by $50 \%$ MF plus rice straw with or without RSDF treatments. While, the treatments of $50 \% \mathrm{MF}$ plus rice straw plus PGPR with or without RSDF were moderated, as these treatments decreased concentration of $\mathrm{N}$ in leaves compared to $100 \% \mathrm{MF}$ without rice straw treatment, whereas there were no significant differences among these treatments in concentrations of $\mathrm{P}$ and $\mathrm{K}$. These findings may be due to addition of rice straw as organic residues into soil, the decomposition of this organic material improves physical, chemical and biological properties of soil, it also improves the nutrient cycling and availability to the plants ( $\mathrm{Yu} \&$ Song, 2003, Abdulla, 2007 and Dai et al., 2010). In addition, the presence of PGPR can increase nitrogen fixation, phosphate dissolving and potassium releasing (Saharan and Nehra, 2011). All these increases of nutrient uptake and promote the nutritional status of eggplant plants. These results are in harmony with those obtained by Shehata et al. (2010) and Shahein et al. (2013) working on celery and lettuce respectively they reported that the biofertilizer increased NPK content in the leaves. 
TABLE 5. Effect of incorporation of rice straw into soil with RSDF and PGPR on NPK percent of eggplant leaves during 2013 and 2014 seasons.

\begin{tabular}{|c|c|c|c|c|c|c|}
\hline \multirow{3}{*}{ Treatments } & \multicolumn{2}{|c|}{$\mathbf{N}$} & \multicolumn{2}{|l|}{$\mathbf{P}$} & \multicolumn{2}{|l|}{$\mathbf{K}$} \\
\hline & \multicolumn{6}{|c|}{$\%$} \\
\hline & $\begin{array}{c}1^{s t} \\
\text { season }\end{array}$ & $\begin{array}{c}2^{\text {nd }} \\
\text { season }\end{array}$ & $\begin{array}{c}1^{s t} \\
\text { season }\end{array}$ & $\begin{array}{c}2^{\text {nd }} \\
\text { season }\end{array}$ & $\begin{array}{c}1^{s t} \\
\text { season }\end{array}$ & $\begin{array}{c}2^{\text {nd }} \\
\text { season }\end{array}$ \\
\hline $100 \% \mathrm{MF}$ (control) & $4.039 \mathrm{~b}$ & $4.192 b$ & $0.352 \mathrm{bc}$ & $0.358 \mathrm{bc}$ & $3.577 \mathrm{~cd}$ & $3.623 \mathrm{~d}$ \\
\hline $100 \% \mathrm{MF}+\mathrm{RS}$ & $4.087 \mathrm{~b}$ & $4.219 \mathrm{~b}$ & $0.370 \mathrm{bc}$ & $0.380 \mathrm{bc}$ & $3.690 \mathrm{bc}$ & $3.828 \mathrm{bc}$ \\
\hline $100 \% \mathrm{MF}+\mathrm{RS}+\mathrm{RSDF}$ & $4.102 b$ & $4.252 \mathrm{~b}$ & $0.403 \mathrm{~b}$ & $0.415 \mathrm{~b}$ & $3.827 \mathrm{~b}$ & $3.969 \mathrm{~b}$ \\
\hline $100 \% \mathrm{MF}+\mathrm{RS}+\mathrm{PGPR}$ & $4.557 \mathrm{a}$ & $4.736 \mathrm{a}$ & $0.577 \mathrm{a}$ & $0.599 \mathrm{a}$ & $4.630 \mathrm{a}$ & $4.840 \mathrm{a}$ \\
\hline $100 \% \mathrm{MF}+\mathrm{RS}+\mathrm{RSDF}+\mathrm{PGPR}$ & $4.667 \mathrm{a}$ & $4.851 \mathrm{a}$ & $0.607 \mathrm{a}$ & $0.628 \mathrm{a}$ & $4.747 \mathrm{a}$ & $4.962 \mathrm{a}$ \\
\hline $50 \% \mathrm{MF}+\mathrm{RS}$ & $2.677 \mathrm{~d}$ & $2.713 \mathrm{e}$ & $0.230 \mathrm{~d}$ & $0.236 \mathrm{~d}$ & $2.350 \mathrm{f}$ & $2.438 \mathrm{f}$ \\
\hline $50 \% \mathrm{MF}+\mathrm{RS}+\mathrm{RSDF}$ & $2.867 \mathrm{~d}$ & $2.905 \mathrm{~d}$ & $0.247 \mathrm{~d}$ & $0.254 \mathrm{~d}$ & $2.557 \mathrm{e}$ & $2.653 \mathrm{e}$ \\
\hline $50 \% \mathrm{MF}+\mathrm{RS}+\mathrm{PGPR}$ & $3.660 \mathrm{c}$ & $3.877 \mathrm{c}$ & $0.327 \mathrm{c}$ & $0.342 \mathrm{c}$ & $3.380 \mathrm{~d}$ & $3.592 \mathrm{~d}$ \\
\hline $50 \% \mathrm{MF}+\mathrm{RS}+\mathrm{RSDF}+\mathrm{PGPR}$ & $3.807 \mathrm{c}$ & $4.004 \mathrm{c}$ & $0.343 \mathrm{c}$ & $0.360 \mathrm{bc}$ & $3.523 \mathrm{~cd}$ & $3.710 \mathrm{~cd}$ \\
\hline
\end{tabular}

Means in same column by similar letters are not statistically different at 0.05 level according to Tukey test.

$\mathrm{MF}=$ mineral fertilizer

$\mathrm{RSDF}=$ rice straw decomposing fungi

$\mathrm{RS} \quad=$ rice straw

PGPR = plant growth promoting rhizobacteria

Data in Table 6 show yield properties (early, total yield and fruits number) of eggplant as affected by the different treatments. In both seasons the results cleared that the highest values of early, total yield and fruit number on plant were obtained by $100 \%$ MF plus rice straw plus PGPR with or without RSDF treatments compared to the other tested treatments. In addition, the treatments of $100 \%$ MF plus rice straw with or without RSDF came in the second order with no significant differences in comparis on with $100 \% \mathrm{MF}$ without rice straw treatment, then the treatments of 50\% MF plus rice straw plus PGPR with or without RSDF came in the third order. finally, the treatments of $50 \% \mathrm{MF}$ plus rice straw with or without RSDF gave the lowest values of early, total yield and fruit number on plant. In general, the most favorable treatments were $100 \% \mathrm{MF}$ plus rice straw plus PGPR with or without RSDF compared with the other treatments. The superiority of these treatments may be due to increased uptake of $\mathrm{N}, \mathrm{P}$ and $\mathrm{K}$ by these plants as shown in Table 4 which resulted in increased plant growth characteristics as shown in Table 3. The improved plant growth led to better carbohydrate build up which increased the early and total yield of eggplant. In this concern, Suge et al. (2011) reported similar results and explained that addition of suitable organic matter in the soil improves the soil physical and chemical properties which encourages better root development, increased nutrient uptake and water holding capacity which leads to higher fruit yield and better fruit quality of eggplant. These results confirmed the study by Man et al. (2003), they indicated that rice straw after harvesting was incorporated into soil within a week by tilling the land with power tiller plus NPK fertilized, grain yield offered higher than treatment of fertilizer without addition of rice straw. These results also supported the finding of Man and $\mathrm{Ha}$ (2006), they mentioned that rice yield in treatment of rice straw after 
decomposition combined with 50\% recommended rate of chemical fertilizer (NPK), was not significantly different from treatment of $100 \%$ recommended rate of chemical fertilizer application.

TABLE 6. Effect of incorporation of rice straw into soil with RSDF and PGPR on early, total yield and fruits number of eggplant during 2013 and 2014 seasons.

\begin{tabular}{|c|c|c|c|c|c|c|}
\hline \multirow{2}{*}{ Treatments } & \multicolumn{2}{|c|}{$\begin{array}{c}\text { Early yield } \\
\mathrm{Kg} / \mathrm{m}^{2}\end{array}$} & \multicolumn{2}{|c|}{$\begin{array}{c}\text { Total yield } \\
\mathrm{Kg} / \mathrm{m}^{2}\end{array}$} & \multicolumn{2}{|c|}{ Fruit No/plant } \\
\hline & \begin{tabular}{|c|}
$1^{\text {st }}$ \\
season
\end{tabular} & $\begin{array}{c}2^{\text {nd }} \\
\text { season }\end{array}$ & $\begin{array}{c}1^{\text {st }} \\
\text { season }\end{array}$ & $\begin{array}{c}2^{n d} \\
\text { season }\end{array}$ & $\begin{array}{c}1^{s t} \\
\text { season }\end{array}$ & \begin{tabular}{|c}
$2^{\text {nd }}$ \\
season
\end{tabular} \\
\hline $100 \% \mathrm{MF}$ (control) & $0.795 \mathrm{~b}$ & $0.760 \mathrm{~b}$ & $3.197 \mathrm{bc}$ & $3.230 \mathrm{bc}$ & $18.18 \mathrm{c}$ & $18.36 \mathrm{c}$ \\
\hline $100 \% \mathrm{MF}+\mathrm{RS}$ & $0.799 \mathrm{~b}$ & $0.764 \mathrm{~b}$ & $3.242 \mathrm{~b}$ & $3.349 \mathrm{~b}$ & $18.83 \mathrm{bc}$ & $18.91 b c$ \\
\hline $100 \% \mathrm{MF}+\mathrm{RS}+\mathrm{RSDF}$ & $0.805 \mathrm{~b}$ & $0.770 \mathrm{~b}$ & $3.269 \mathrm{~b}$ & $3.351 \mathrm{~b}$ & $19.04 \mathrm{~b}$ & $19.45 b$ \\
\hline $100 \% \mathrm{MF}+\mathrm{RS}+\mathrm{PGPR}$ & $1.052 \mathrm{a}$ & $1.089 \mathrm{a}$ & $4.360 \mathrm{a}$ & $4.368 \mathrm{a}$ & $24.31 \mathrm{a}$ & $24.38 \mathrm{a}$ \\
\hline $100 \% \mathrm{MF}+\mathrm{RS}+\mathrm{RSDF}+\mathrm{PGPR}$ & $1.062 \mathrm{a}$ & $1.099 \mathrm{a}$ & $4.473 \mathrm{a}$ & $4.482 \mathrm{a}$ & $24.95 \mathrm{a}$ & $25.01 \mathrm{a}$ \\
\hline $50 \% \mathrm{MF}+\mathrm{RS}$ & $0.283 \mathrm{f}$ & $0.248 \mathrm{f}$ & $2.063 \mathrm{e}$ & $2.073 \mathrm{f}$ & $11.50 \mathrm{f}$ & $11.56 \mathrm{f}$ \\
\hline $50 \% \mathrm{MF}+\mathrm{RS}+\mathrm{RSDF}$ & $0.373 \mathrm{e}$ & $0.338 \mathrm{e}$ & $2.243 \mathrm{~d}$ & $2.256 \mathrm{e}$ & $12.52 \mathrm{e}$ & $12.59 \mathrm{e}$ \\
\hline $50 \% \mathrm{MF}+\mathrm{RS}+\mathrm{PGPR}$ & $0.627 \mathrm{~d}$ & $0.594 \mathrm{~d}$ & $3.078 \mathrm{c}$ & $3.088 \mathrm{~d}$ & $17.20 \mathrm{~d}$ & $16.99 \mathrm{~d}$ \\
\hline $50 \% \mathrm{MF}+\mathrm{RS}+\mathrm{RSDF}+\mathrm{PGPR}$ & $0.712 c$ & $0.679 \mathrm{c}$ & $3.082 \mathrm{c}$ & $3.118 \mathrm{~cd}$ & $17.20 \mathrm{~d}$ & $17.40 \mathrm{~d}$ \\
\hline
\end{tabular}

Means in same column by similar letters are not statistically different at 0.05 level according to Tukey test.

$\mathrm{MF}=$ mineral fertilizer $\quad \mathrm{RS}=$ rice straw

$\mathrm{RSDF}=$ rice straw decomposing fungi $\quad$ PGPR $=$ plant growth promoting rhizobacteria

\section{Conclusions}

In conclusion, this study showed that application of rice straw into soil with rice straw decomposing fungi and plant growth promoting rhizobacteria, improved the production of eggplant in the clay soil at Giza governorate, Egypt. As well as reduced the amount of mineral fertilizers and avoid the serious environmental air pollution (Black Cloud), caused by the burning of rice straw annually.

\section{References}

Abdulla, H.M. (2007) Enhancement of rice straw composting by lignocellulolytic actinomy cete strains. Int. J. Agri. Biol., 9 (1), 106-109.

Abou Hussein, S.D. and Sawan, O.M. (2010) The utilization of agricultural waste as one of the environmental issues in Egypt. J. Appl. Sci. Res., 6 (8), 1116-1124.

Chapman, H.D. and Pratt, P.F. (1961) Methods of Analysis for Soil, Plant and Water, Division of Agric. Sci., Calif. Univ.

Egypt. J. Hort. Vol. 42, No. 2 (2015) 
Cottenie, A, Verloo, M., Kiekers, L., Velghe, G. and Camrbynek, R. (1982) "Chemical Analysis of Plants and Soils", Hand Book, 1-63, Ghent, Belgium.

Dai Z.G, Lu, J.W., Li, X.K., Lu, M.X., Yang, W.B. and Gao, X.Z. (2010) Nutrient release characteristic of different crop straws manure. Trans., CSAE, 26 (6), 272-276.

FAO (Food and Agriculture Organization) (1980) Soil and Plant Analysis, Soils Bulletin, 38 (2), 250.

Glinwood, R., Ninkovic, V. and Pettersson, J. (2011) Chemical interaction between undamaged plants - Effects on herbivores and natural enemies. Phytochem., 72 (13), 1683-1689.

Hou, Y, Hu, X. and Zhou, B. (2012) Hot pepper growth promotion and inhibition of fusarium wilt with different crop stalks. Afr. J. Agric. Res., 7 (35), 5005-5011.

Irfan, M, Syed, Q., Yousaf, M., Nadeem, M., Baig, S. and Jafri, S.A. (2010) Studies on the Pretreatment of wheat straw for improve production of Carboxymethyl Cellulase by thermophilic Trichoderma viride- FBL1 in Solid State fermentation. Academia Arena, 2 (7), 18-30.

Joseph, B, Patra, R.R. and Lawrence, R. (2007) Characterization of plant growth promoting rhizobacteria associated with chickpea. International Journal of Plant Production, 1 (2), 141-152.

Kausar, H, Sariah, M., Saud, H.M., Alam, M.Z. and Ismail, M.R. (2010) Development of compatible lignocellulolytic fungal consortium for rapid composting of rice straw. Inter. Biodeter Biodegrad, 64 (7), 594-600.

Latha, P, Jeyaraman, S. and Prabakaran, R. (2014) Effect of microbial and chemical fertilizer on eggplant. Int. J. Pure App. Biosci., 2 (4), 119-124.

Man, L.H. and Ha, N.N. (2006) Effect of decomposed rice straw at different times on rice yield. Omonrice, 11, 74-82.

Man, L.H., Khang, V.T. and Watanabe, T. (2003) Improvement of soil fertility by rice straw manure. Omonrice, 11, 74-82.

Mashhoor, W.A, El-Borollosy, M.A., Abdel-Azeem, H.H.A., Nasr, S.A. and Selim, S.M. (2002) Biofertilization of wheat plants exposed to environmental conditions. $J$. Agric. Sci, Ain Shams Univ., 10 (2), 543-565.

Ministry of Agriculture and Land Reclamation, Economic Affairs Sector (2013) Bulletin of The Agriculture Statistics.

Ministry of Agriculture and Land Reclamation (2009) Symptoms of nutrient deficiency on some field and horticultural crops. Soils, Water and Environ. Res. Inst., Agric. Res. Center.

Nandi, N, Rahman, F.H., Sinha, N.B. and Hajra, J.N. (2000) Compatibility of lignindegrading and cellulose decomposing fungi during decomposition of rice straw. $J$. Indian Soc. Sci., 48 (2), 387-389. 
Saharan, B.S. and Nehra, V. (2011) Plant Growth Promoting Rhizobacteria: A Critical Review. Life Sciences and Medicine Research, 21.

Shahein, M.M, Abou El-Hassan, S. and Ragab, A.A. (2013) Reduction of mineral fertilizers in lettuce production by using microbial inoculation, potassium humate and potassium silicate. Hortscience J. Suez Canal University, 1, 77-84.

Shehata, S.M, Abdel-Azem, H.S., Abou El-Yazied, A. and El-Gizawy, A.M. (2010) Interactive effect of mineral nitrogen and biofertilization on the growth, chemical composition and yield of celeriac plant. European Journal of Scientific Research, 47 (2), 248-255.

Sirisena, D.M. and Manamendra, T.P. (1995) Isolation and characterization of cellulolytic bacteria from decomposing rice straw. J Natu. Sci. Coun. Sri Lanka, 23 (1), 25-30.

Snedecor, G.W. and Cochran, W.G. (1980) "Statistical Methods", $6^{\text {th }}$ ed., Iowa State University Press, Ames., Iowa, U.S.A.

Suge, J.K, Omunyin, M.E. and Omami, E.N. (2011) Effect of organic and inorganic sources of fertilizer on growth, yield and fruit quality of eggplant (Solanum Melongena L). Arch. Appl. Sci. Res., 3 (6), 470-479.

Watanabe, F.S. and Olsen, S.R. (1965) Test of an ascorbic acid method for determining phosphorus in water and $\mathrm{Na} \mathrm{HCO}_{3}$ extracts from soil. Soil Sci. Soc. Amer. Proc., 29, $677-678$.

Yu, Z.D. and Song, S.Y. (2003) Effects of straw mixed with biopreparate on improvement of soil in greenhouse. Trans. CSAE, 19,177-179.

Zenia, M. and Halinam, B. (2008) Content of microelements in eggplant fruits depending on nitrogen fertilization and plant training method. J. Elementol., 13 (2), 269-274.

(Received 9/10/2014; accepted $11 / 2 / 2015)$ 


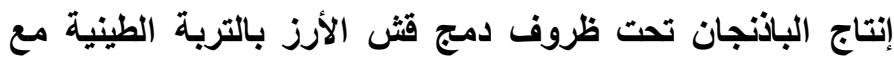
الفطريات المحللة ويكتريا منطقة الجذور المشجعة لنمو النبات النبات

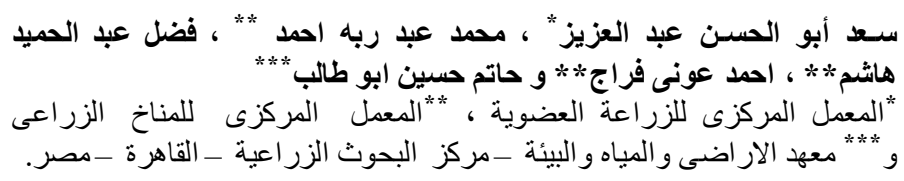

أجريت تجربة حقلية بتربة طينية فى الموقع البحثى التابع للمعدل المركزى للمناخ

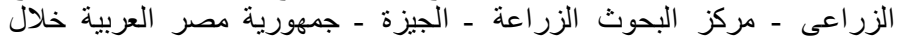

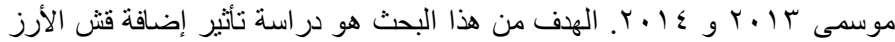

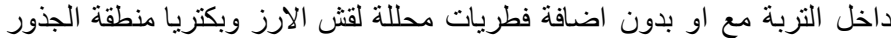

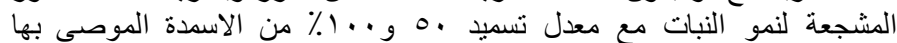
لعناصر ن، فو، بو على إنتاج الباذنجان. استخدم تصميم قطاعات كاملة معلة العشوائية

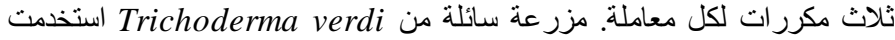

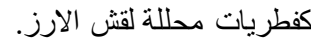
مخلوط من البكتريا التالية:

Azotobacter chroococcum, Azospirillium brasilense, $B$. ا megaterium, B. circulans

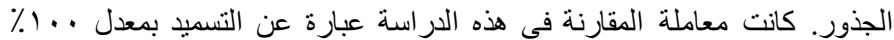

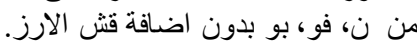

أظهرت النتائج المتحصل عليها تحسن معنوى فى صفات النمو الخضات النّرى

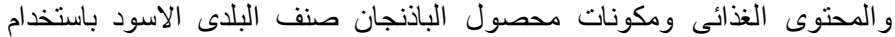

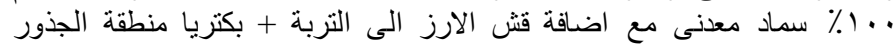

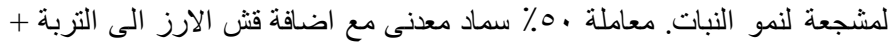

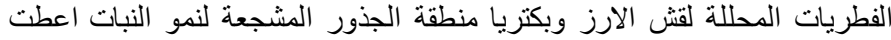

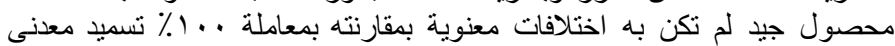
بدون اضافة قش الارز.

اوضحت هذه الدراسة ان اضافة قش الارز الى التربة مع الفطريات المحللة

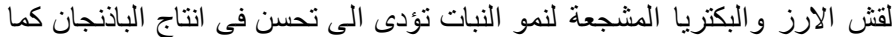

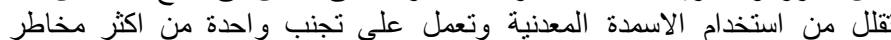

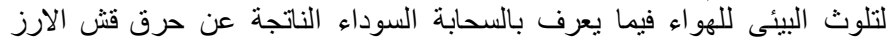

